\title{
Reconstruction of a full-thickness alar wound using an auricular conchal composite graft
}

\author{
Marco Klinger MD, Luca Maione MD, Federico Villani MD, \\ Fabio Caviggioli MD, Davide Forcellini MD, Francesco Klinger MD
}

\begin{abstract}
M Klinger, L Maione, F Villani, F Caviggioli, D Forcellini, F Klinger. Reconstruction of a full-thickness alar wound using an auricular conchal composite graft. Can J Plast Surg 2010;18(4):149-151.

Nasogastric intubation has become a frequently used method for alleviating gastrointestinal symptoms. Necrosis from alar pressure during prolonged nasogastric and nasotracheal intubation is common, and can result in considerable deformity if it is unrecognized. The reconstruction of full-thickness alar wounds often requires multiple challenging surgical procedures. Difficult full-thickness alar defects often require nasal mucosal replacement for lining, cartilage batten graft support for the preservation of nasal function, and skin coverage for the restoration of an aesthetically correct appearance. Free composite conchal grafting can offer a single-staged, one-step repair of difficult full-thickness alar wounds that are no larger than $1.5 \mathrm{~cm}$ in size. A thorough explanation of the graft design and execution is presented, as well as a case report and literature review. Free composite conchal grafting can produce aesthetic and functional results that rival the most sophisticated flap reconstructions of the lateral ala.
\end{abstract}

Key Words: Alar defect; Graft; Nasogastric tube; Nose

\section{La reconstruction d'une lésion de toute l'épaisseur de l'aile du nez au moyen d'une greffe composite du cartilage du pavillon de l'oreille}

\begin{abstract}
L'intubation nasogastrique est une méthode fréquente pour soulager les symptômes gastro-intestinaux. La nécrose causée par une pression sur l'aile du nez pendant une intubation nasogastrique et nasotrachéale prolongée est courante et peut provoquer une malformation importante si elle n'est pas dépistée. La reconstruction de lésions de toute l'épaisseur de l'aile du nez exige souvent de multiples interventions chirurgicales difficiles. Pour corriger ces anomalies, il faut souvent remplacer la muqueuse nasale de la paroi, soutenir la greffe par du cartilage afin de préserver la fonction nasale et recouvrir le tout de peau pour rétablir une apparence esthétique convenable. Les greffes composites gratuites de pavillon de l'oreille peuvent réparer en une seule étape des lésions de toute l'épaisseur de l'aile du nez qui ne dépassent pas $1,5 \mathrm{~cm}$. La conception et l'exécution de la greffe sont expliquées en détail, et un rapport de cas et une analyse bibliographique sont présentés. Les greffes composites gratuites de pavillon de l'oreille peuvent produire des résultats esthétiques et fonctionnels qui rivalisent avec les reconstructions par lambeau de l'aile latérale du nez, plus compliquées.
\end{abstract}

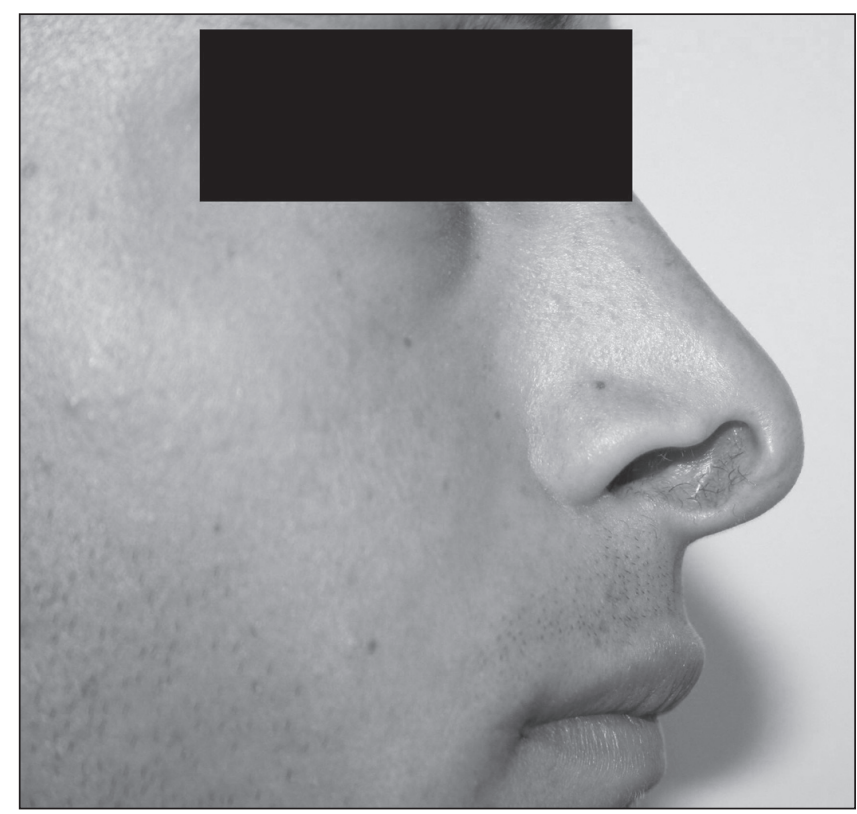

Figure 1) Alar defect

The lesion had been caused by pressure from a nasogastric tube placed immediately following birth to provide nutrition to the
Since its first description by Hunter in 1790 (1), nasogastric $\checkmark$ intubation has become a frequently used method for alleviating gastrointestinal symptoms. Currently, nasogastric tube placement is the route of choice for providing nutrition to premature infants who are unable to receive oral nutrition $(2,3)$. Malposition of nasogastric tubes can have disastrous consequences for the patient. Necrosis from alar pressure during prolonged nasogastric and nasotracheal intubation is common, and can result in considerable deformity if it is unrecognized. Restoring the natural shape of the nasal ala is a particularly difficult task that requires thoughtful planning (4). The reconstructive strategy will vary with the depth of the defect. The shape of the nose is defined by its underlying supporting structures such as bone, cartilage, muscle and fibrofatty tissue. The alar cartilages that support the lobule consist of the medial and lateral crus and are joined by soft tissue ligaments to the lateral and septal cartilages of the nose. We describe a composite chondrocutaneous graft harvested from the antitragus to repair a full-thickness alar defect of the nostril.

\section{CASE PRESENTATION}

In November 2008, a 20-year-old man was referred to the plastic surgery unit. On examination, the patient exhibited a large scar (approximately $2 \mathrm{~cm} \times 1.5 \mathrm{~cm}$ ) in the right side of his nose, shrinking concentrically with distortion of the nasal tip (Figure 1).

Università degli Studi di Milano, Cattedra di Chirurgia Plastica - Unità Operativa di Chirurgia Plastica 2, IRCCS Istituto Clinico Humanitas, Milano, Italy Correspondence: Dr Fabio Caviggioli, Cattedra di Chirurgia Plastica, Università degli Studi di Milano, Unità Operativa di Chirurgia Plastica 2 , IRCCS Istituto Clinico Humanitas, Via Manzoni 56, 20089 Rozzano, Milano, Italy. Telephone 39-028-224-6443, fax 39-028-224-2298, e-mail fabio.caviggioli@humanitas.it 


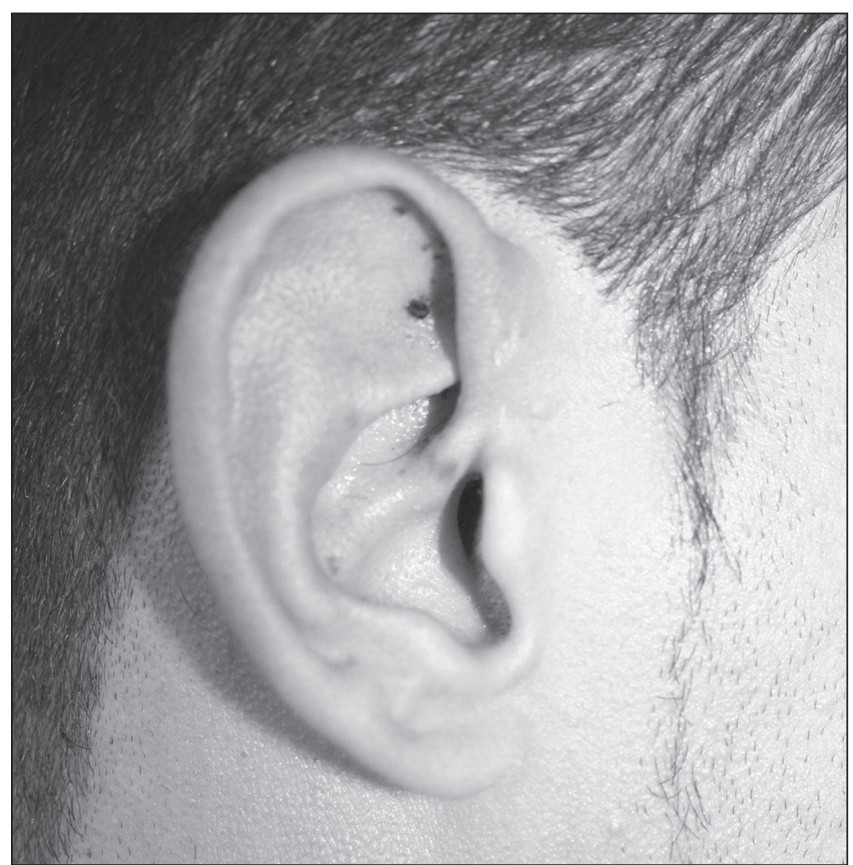

Figure 2) Donor site two months after operation

premature infant who had feeding difficulties. Necrosis from alar pressure during prolonged nasogastric intubation resulted in considerable deformity. The defect was responsible for partial collapse of the nasal airway and produced an alteration of the external appearance. The patient was scheduled for an elective repair of the nasal ala defect.

After the graft had been adequately planned, the donor and recipient sites were infiltrated with $1 \%$ lidocaine plus adrenaline. The surgical incision allowed full-thickness removal of the entire scar of the right nasal ala. The incision was made so that the sutures approximated the natural contours of the nose. An exact template was created using the silver paper envelope of the suture packaging, and a composite conchal graft was harvested. The donor site was precisely marked for through-and-through nasal alar defect repair. The composite graft consisted of fullthickness anterior skin and cartilage. The donor site was closed with simple interrupted sutures, and the batten graft was trimmed to fit the defect (Figure 2). Lining was obtained from an intranasal advancement flap. Final closure camouflaged all incisions well; complete repair of the defect with excellent wound healing was obtained with good results, both from functional and aesthetic viewpoints (Figure 3).

\section{DISCUSSION}

Nasal defects are usually defined as 'total' or 'subtotal' $(5,6)$. Based on anatomy, Bayramiçli (7) proposed a new and comprehensive system for scoring and classifying nasal defects, providing a useful algorithm to approach nasal reconstruction. A basic premise of nasal reconstruction dictates that missing tissue should be replaced with similar tissue harvested from adjacent or remote locations.

The anatomy of the lower one-third of the nose is a single subunit, different from the proximal two-thirds. The skin of the lower one-third has limited mobility and, therefore, can be recruited only for closure of small defects. The colour and sebaceous texture are unique; thus, neither distant nor local flaps

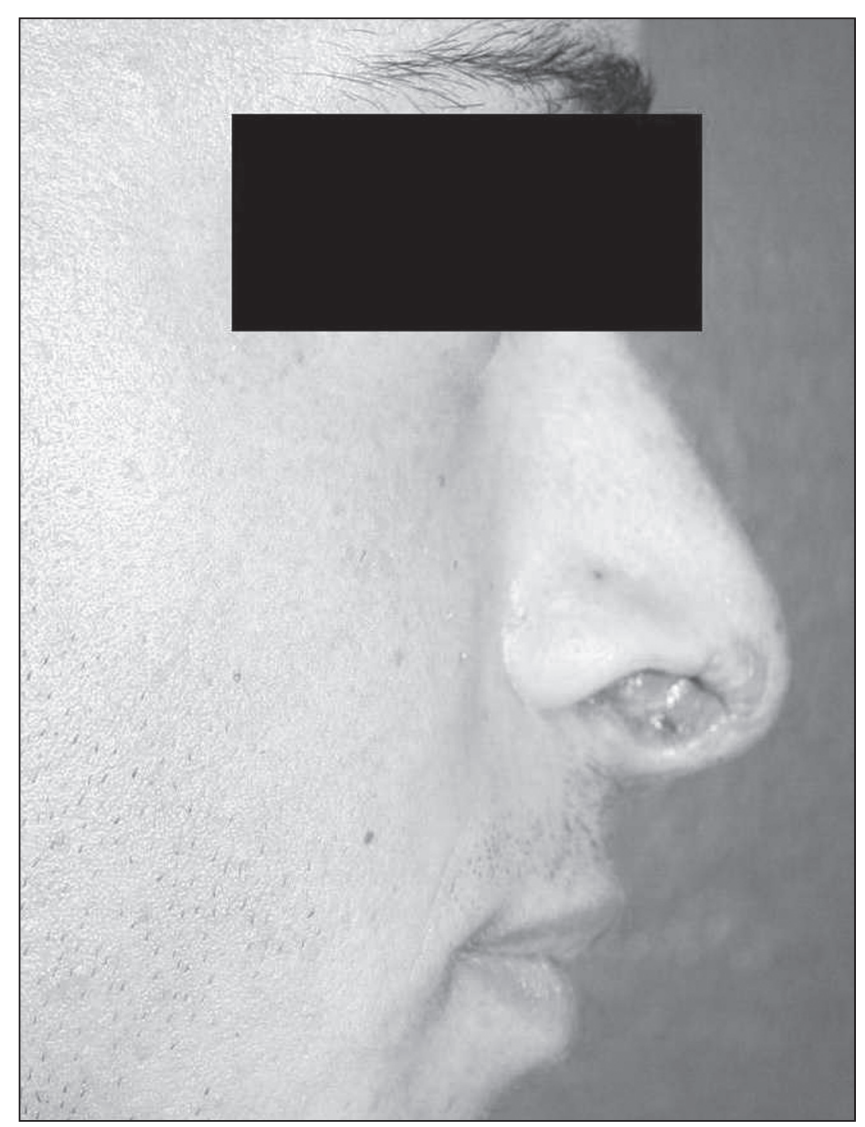

Figure 3) Two months after operation

are good matches. Finally, the free margin of the alar rims is mobile and easily distorted by imprecise closures.

International guidelines suggest that surgical reconstruction replaces skin cover, skeletal support and lining; the topographic subunits determine the aesthetic plan (8).

Numerous techniques for reconstruction of the nasal ala have been proposed over the years, including skin grafts, composite grafts and various local flaps.

Healing by secondary intention should be considered only for small defects. Side-to-side closure may be performed on small defects in the alar groove or perpendicular to the rim, but not involving the rim. A multitude of local flaps can be used, although some flaps cannot be mobilized in young patients with taut skin; it is extremely difficult to exactly reproduce the natural arch of the ala and its boundary with the cheek.

Grafting may be an attractive alternative for defects involving all or most of a nasal subunit (eg, dorsum, sidewall and tip) in a patient with thin, poorly sebaceous skin. If the defect involves the alar rim, a skin graft from the preauricular, postauricular or supraclavicular regions may be a better solution. Skin grafts are often the preferred repair option in younger patients because they lack sufficient skin laxity to execute a local flap.

Conchal skin is a good match (9). A perichondrial cutaneous composite graft from the concha may contract less and minimize distortion of the alar rim. Free composite conchal grafting is ideal for through-and-through alar defects (10).

The conchal cartilage is an excellent donor tissue because it mimics the natural arch of the nasal ala, is elastic and has a 
high degree of memory (11-13). The entire conchal base can be removed without significant risk of auricular distortion. A narrow strip that spans the ala will usually suffice. The curved cartilaginous strip is placed over the lining flap and sutured medially to the septal cartilage or to the remaining alar cartilage, and laterally to the soft tissue of the alar base. Nasal valve patency should be achieved and can be confirmed by viewing the alar contour from below. Occasionally, the surgeon must realign the cartilage graft for optimal effect. Patients will subjectively detect improved nasal air passages. A conchal composite graft should not contract, thus minimizing distortion of the alar rim $(14,15)$. Free composite conchal grafting may provide a single-staged closure with good colour and texture match with nasal ala. Limitations include variability and unpredictability of ultimate graft survival. It should not be performed in smokers and patients with small-vessel disease, such as diabetes or coronary artery disease, and the defect must be less than $1.5 \mathrm{~cm}$ in its greatest dimension, be exposed to minimal intraoperative trauma and be constantly kept moist intraoperatively. The major advantages to composite conchal grafting are that it is autologous tissue, has a similar contour to that of the alar rim and establishes patency of the nasal valve. Disadvantages are the creation of an additional surgical wound and associated potential comorbidities, such as chondritis or infection, which are rare. In patients with fullthickness alar defects, cartilage grafts serve as a useful adjunct to cutaneous closure. We have achieved good to excellent functional and cosmetic results in the majority of cases, with minimal morbidity.

A through-and-through defect, defined as one that extends through the entire thickness of the ala so as to penetrate the mucosal lining, requires reconstructive strategies that recreate

\section{REFERENCES}

1. Phillips NM. Nasogastric tubes: An historical context. Medsurg Nurs 2006;15:84-8.

2. Ellett ML, Beckstrand J. Examination of gavage tube placement in children. J Soc Pediatr Nurs 1999;4:51-60.

3. Ellett ML, Croffie JM, Cohen MD, Perkins SM. Gastric tube placement in young children. Clin Nurs Res 2005;14:238-52.

4. Schultz-Coulon HJ. Repair of postintubational lesions of the cartilaginous nose in infants - sometimes a surgical problem. Int J Pediatr Otorhinolaryngol 1984;7:119-31.

5. Barton FE Jr. Nasal reconstruction. In: Smith JW, Aston SJ, eds. Grabb and Smith's Plastic Surgery, 4th edn. Boston: Little, Brown and Co, 1991:491-505.

6. Rohrich RJ, Barton FE, Hollier L. Nasal reconstruction. In: Aston SJ, Beasley RW, Thorne CH, eds. Grabb and Smith's Plastic Surgery, 5th edn. Philadelphia: Lippincott-Raven Publishers, 1997:513-28.

7. Bayramiçli M. A new classification system and an algorithm for the reconstruction of nasal defects. J Plast Reconstr Aesthet Surg 2006;59:1222-32.

8. Burget GD, Menick FJ. The subunit principle in nasal reconstruction. Plast Reconstr Surg 1985;76:239-47. lining, support and cover. This entails replacement of mucosa, supporting cartilage (if required for form and function) and overlying skin. Lining flaps are critical components of the repair of a full-thickness alar defect because inadequate replacement can cause airway obstruction and contraction of the overlying flap. Lining for the ala can be derived from several sources: intranasal advancement flap, septal hinge flap, oral mucosal graft, hinge flap from nasal sidewall, nasolabial flap or full-thickness skin graft. Nasal mucosa, superior or medial to the defect, can be advanced to cover it and the secondary defect may be left to re-epithelialize for secondary intention $(16,17)$.

\section{CONCLUSIONS}

Difficult full-thickness alar defects often require nasal mucosal replacement for lining, cartilage batten graft support for the preservation of nasal function, and skin coverage for the restoration of an aesthetically proper appearance. Free composite conchal grafting may provide a single-staged closure. Understandably, such involved nasal reconstructions test the abilities of even the most talented and experienced plastic surgeon. Moreover, the multitude of separate and distinct procedures required to replace a missing ala introduces operative risks, significant surgeon and patient time investment, and extraordinary costs.

CONFLICT OF INTEREST: None of the authors have any commercial associations or other arrangements (eg, financial compensation received, patient-licensing arrangements, potential to profit, consultancy, stock ownership, etc) that may pose a conflict of interest in connection with the article.

9. Rohrer TE, Dzubow LM. Conchal grafting in nasal tip reconstruction: Clinical and histological evaluation. J Am Acad Dermatol 1995;33:476-81.

10. Robinson JK, Burget GC. Nasal valve malfunction resulting from resection of a cancer. Arch Otolaryngol Head Neck Surg 1990;116:1419-24.

11. Otley CC, Sherris DA. Spectrum of cartilage grafting in cutaneous reconstructive surgery. J Am Acad Dermatol 1998;39:982-92.

12. Quatela VC, Jacono AA. Structural grafting in rhinoplasty. Facial Plast Surg 2002;18:223-32.

13. Becker DG, Becker SS, Saad AA. Auricular cartilage in revision rhinoplasty. Facial Plast Surg 2003;19:41-51.

14. Love CW, Collison DW, Carithers JS, Ceilley RI. Perichondrial cutaneous grafts for reconstruction of skin cancer defects. Dermatol Surg 1995;21:219-22.

15. Maves M, Yessenow R. The use of composite auricular grafts in nasal reconstruction. J Dermatol Surg Oncol 1988;114:994-9.

16. Burget GC, Menik FJ. Nasal reconstruction: Seeking a fourth dimension. Plast Reconstr Surg 1986;78:145-57.

17. Barton FE. Aesthetic aspects of nasal reconstruction. Clin Plast Surg 1988;15:155-65. 